\title{
Lactic acid bacteria mediated induction of defense enzymes to enhance the resistance in tomato against Ralstonia solanacearum causing bacterial wilt
}

\author{
Narasimha Murthy Konappa ${ }^{a, *}$, Malini Maria ${ }^{a}$, Fazilath Uzma ${ }^{a}$, Soumya Krishnamurthy ${ }^{\mathrm{a}}$, \\ Siddaiah Chandra Nayaka ${ }^{\mathrm{b}}$, Siddapura Ramachandrappa Niranjana ${ }^{\mathrm{b}}$, \\ Srinivas Chowdappa ${ }^{\text {a }}$ \\ a Department of Microbiology and Biotechnology, Jnanabharathi Campus, Bangalore University, Bangalore, 560 056, India \\ b Department of Studies in Biotechnology, University of Mysore, Mysore, 570 006, India
}

\section{A R T I C L E I N F O}

\section{Article history:}

Received 19 January 2016

Received in revised form 25 May 2016

Accepted 27 May 2016

Available online 14 June 2016

\section{Keywords:}

Lactobacillus paracasei

Ralstonia solanacearum

Induced systemic resistance

Tomato

Bacterial wilt

\begin{abstract}
A B S T R A C T
The biocontrol agent Lactic acid bacterium (LAB) was used against the bacterial wilt caused by Ralstonia solanacearum. The present investigation focuses on the role of defense related enzymes in imparting resistance to tomato plants against $R$. solanacearum. The LAB isolate was tested for its ability to induce the production of defense-related enzymes in treated tomato seedlings. Tomato seedlings were raised from LAB pretreated seeds, were challenge inoculated with $R$. solanacearum, harvested at different time intervals (0-72 h) and assayed for defense enzyme activity. The LAB treated seeds showed increase in germination percentage (6\%) and seedling vigour index (259) compared with control. Treatment of tomato seedlings with LAB isolate induced a significant amount of Peroxidase (POX), Polyphenol oxidase (PPO), Phenylalanine ammonialyase (PAL), total phenolics and $\beta$-1,3-glucanase activities. The activities of PAL, POX, PPO and $\beta$-1,3-glucanase reached maximum at $24 \mathrm{~h}, 24 \mathrm{~h}, 32 \mathrm{~h}$ and $24 \mathrm{~h}$ respectively after challenge inoculation. Increased accumulation of phenolics was noticed in plants pre-treated with LAB. Native PAGE analyses of POX and PPO were carried out for the time course of enzyme activities and the isoforms of POX and PPO were examined. In field study, ten isolates of $R$. solanacearum treated plots yielded an average of $32.4-50 \mathrm{~kg} / \mathrm{m}^{2}$ and $\mathrm{LAB}$ treated plots an average of $153.5 \mathrm{~kg} / \mathrm{m}^{2}$. As compared to the control, LAB increased the yield by $15.3 \%\left(8.2 \mathrm{~kg} / \mathrm{m}^{2}\right)$ and the pathogen infected plants and pre-treated with $\mathrm{LAB}$ gave an average of $55 \%\left(28.3 \mathrm{~kg} / \mathrm{m}^{2}\right.$ compared to the infected plots). Field experiment results indicated that LAB exhibited $61.1 \%$ of disease reduction of bacterial wilt in tomato.
\end{abstract}

(C) 2016 Elsevier B.V. All rights reserved.

\section{Introduction}

Tomato (Lycopersicon esculentum) is a widely consumed vegetable crop worldwide (Ronga et al., 2015), which is also an excellent source of vitamin A, vitamin C, iron and phosphorus. In tropical Asia it is an important cash crop of small farmers (Villareal, 1979) and tops the list of industrial crops because of its outstanding processing qualities. It is a short duration, high yielding crop, and hence it is economically important. Its area of cultivation is increasing steadily. The major constraint to tomato production in India is bacterial wilt caused by Ralstonia solanacearum (Yabuuchi et al.,

\footnotetext{
* Corresponding author.

E-mail addresses: n.murthy10@yahoo.com,n.murthy10@gmail.com (N.M. Konappa).
}

1995), with a host range exceeding 200 species covering over 50 families (Aliye et al., 2008). High pathogen variability, high survival rate under diverse environmental conditions and its extremely wide host range renders the disease difficult to control. Chemical treatments are short lived and less effective. Therefore, the stratagem of biocontrol has evolved itself as a promising approach to create long lasting effect and facilitating sustainable agriculture (Nagorska et al., 2007). Lactic acid bacteria (LAB) are known as probiotic organisms and are generally recognized as safe (Stiles and Holzapfel, 1997). Lactic acid bacteria are reported to produce various antibacterial compounds, such as acetic acid, lactic acid, hydrogen peroxide, several bacteriocins and even antifungal compounds (Ariyapitipun et al., 1999). Lactic acid bacterial cultures or their supernatants have been used as biological control agents on plant diseases in chilli, tomato and cucumber caused by Colletotrichum capsici (El-Mabrok et al., 2012), Fusarium oxysporum and 
Pythium ultimum respectively (Lutz et al., 2012). Several species of LAB have been recognized as producers of bioactive metabolites that act against a broad spectrum of undesirable microorganisms such as fungi, oomycetes and other bacteria (Axel et al., 2012). Lactic acid bacteria are commonly found in fresh fruits, vegetables, soil, and milk products and pose no risk to human or animal health. Lactobacillus plantarum, Lactobacillus acidophilus, Lactobacillus buchneri, Leuconostoc spp., and Weissella cibaria isolated from fresh fruits and vegetables showed in vitro antagonistic activity in overlay assay. Lactic acid bacteria possess different modes of action, mainly in the production of organic acids, hydrogen peroxidase and siderophores which can prove effective for biocontrol. Also LAB isolated from fresh fruits and vegetables are reported to decrease the infection of phytopathogenic and spoilage bacteria and fungi namely Xanthomonas campestris, Erwinia carotovora, Monilinia laxa, and Botrytis cinerea on apple fruits. Lactic acid bacteria are a promising bacterial group to suppress soil-borne diseases and to promote plant growth (Matthias et al., 2012). The ability of LAB to suppress certain fungi has been shown in the control of post-harvest diseases of fruits and vegetables. Besides, LAB has also other properties making them interesting candidates for the biological control of soil-borne pathogens. The technology for mass production of LAB is readily available in the food industry.

Resistance development, ground water and foodstuff pollution and the oncogenic risk developments among the pathogens have led to the exploitation of potential antagonistic microflora as biocontrol agents in disease management. According to Van Loon et al. (1998), Induced systemic resistance (ISR) is a state of increased defensive capacity developed by the plant when appropriately stimulated through activation of latent resistance mechanisms induced by diverse agents, including rhizobacteria. They typically promote plant growth in two ways that is direct stimulation and biocontrol (Glick, 1995). Plant growth promoting rhizobacteria (PGPR) are the bacteria that reside in the rhizosphere and improve plant health eventually aiding to supplement plant growth (Goswami and Thakker Dhandhukia, 2016). PGPRs are the potential tools for sustainable agriculture and tendency for the future. A thorough understanding of the plant growth-promoting (PGP) mechanics is predictable to manipulate the rhizosphere flora in order to exploit the processes that strongly improve plant productivity. PGP mechanisms have been grouped into direct and indirect mechanisms. Direct mechanism includes the stability of plant growth regulators. Microorganisms themselves liberate growth regulators or act as a sink of plant released hormones that induce the plant's metabolism leading to an development in its adaptive capability (Glick, 2014). Indirect mechanisms are those that happen outside the plant, while direct mechanisms are those that occur inside the plant and directly affect the plant's metabolism (Siddikee et al., 2010). Two main mechanisms are included in indirect group, induction of systemic resistance against pathogens (biotic stress) and protection against unhealthy environment conditions (abiotic stress) (Glick, 2014).

Many induced systemic resistance enzymes are involved in redirecting the flow of carbon from primary to secondary metabolism in plants, such as phenylalanine-ammonialyase (PAL), Peroxidase (POX) and Polyphenol oxidase (PPO)-the key enzymes in the synthesis of phenolic compounds with antimicrobial activity. However, less is known about kinetic changes in defense-related enzymes caused by LAB strains on tomato. Lactic acid bacteria form an ecologically heterogeneous group of Gram positive bacteria, nonspore forming, immobile and catalase negative that excretes lactic acid as major end product and generally recognized as safe (GRAS) organisms.

Plants have several lines of defense against invading pathogens including preformed barriers and induced responses. The ISR once expressed activates multiple defense mechanisms including increased activity of POX, PPO and PAL (Chen et al., 2000). ISR develops either locally or systemically in response to a pathogen and is associated with an increase in the activity of chitinases, $\beta$ 1,3-glucanases and peroxidases (Van Loon, 1997). Plants possess a range of active defense responses that contribute to resistance against a variety of pathogens and respond to bacterial pathogen attack by activating various responses that are associated with the accumulation of several factors like defense related enzymes and inhibitors that serve to prevent pathogen infection (Girish and Umesha, 2005). Systemic acquired resistance is characteristically associated with accumulation of salicylic acid, enhanced expression of pathogenesis-related proteins and activation of phenylpropanoid pathway, leading to the synthesis of higher phenolic compounds. Phenolics have been associated extensively with the defense of plants against microbes, insects and other herbivores (Metraux and Raskin, 1993). Phenylalanine ammonialyase is the first enzyme in the phenylpropanoid pathway that catalyses the conversion of L-phenylalanine to trans-cinnamic acid which in turn enters different biosynthetic pathways leading to lignin synthesis, a major product of phenylpropanoid metabolism and a key intermediate in the synthesis of salicylic acid. This defense mechanism is used for protection against pathogen invasion, induction of PAL as a response to pathogen infection which is well documented in various host-pathogen interactions (Kavitha and Umesha, 2008). Peroxidase is a defense-related enzyme, with broad spectrum activity and it plays key roles in plant-pathogen interactions. POX is believed to be one of the most significant factors of the plant's biochemical defense against pathogenic microorganisms, and is actively involved in self regulation of plant metabolism after infection (Roohie and Umesha, 2015).

Polyphenol oxidase is a copper containing antioxidant enzyme that oxidizes phenolics to highly toxic quinines and contributes to disease resistance; quinones are presumably toxic to pathogens and also play a significant role in the lignin biosynthesis. PPO catalyses the oxidation of phenolic compounds to highly toxic quinones which play an important role in plant disease resistance. The enzyme is localized in the plastids, whereas its phenolic substrates are present mainly in the vacuole (Umesha, 2006). PPO has been implicated as functioning in the defense mechanism against insects and plant pathogens. Higher levels are seen in tolerant cultivars than in susceptible ones (Das et al., 2004).

The objectives of the present study include characterization and evaluation of Lactic acid bacteria isolated from soil for induction of defense enzymes such as phenylalanine ammonialyase, guaiacol peroxidases, polyphenol oxidase, $\beta$-1,3-glucanase and total phenolics by challenge inoculation with $R$. solanacearum.

\section{Materials and methods}

\subsection{Isolation and identification of $\mathrm{R}$. solanacearum}

The suspected plant material and soil samples were collected from the wilted tomato fields Isolation from rhizosphere soil samples (serial dilution plate technique) and surface sterilized plant shoot sections $(0.5-1 \mathrm{~cm})$ was done on Kelman's TZC (2,3,5-Triphenyl tetrazolium chloride) medium (Kelman, 1954). The plates were incubated at $28 \pm 2{ }^{\circ} \mathrm{C}$ for $24-48 \mathrm{~h}$. Total DNA was extracted from ten isolates selected based on pathogenicity assay as described by Chen and Kuo (1993). The 16S rRNA gene was amplified by PCR with universal primers: 8F (5'-AGAGTTTGATCCTGGCTCAG-3') and 806R (5'GGACTACCAGGGTATCTAAT-3') (Lane, 1991). Master mixture was prepared with PCR reagents and distributed into $200 \mu \mathrm{l}$ PCR tubes. The reaction volume of $50 \mu \mathrm{l} /$ reaction was maintained which comprised of $1 \mu \mathrm{l}$ of each primers ( $20 \mathrm{pmol}$ Concentration), $5 \mu \mathrm{l}$ of 

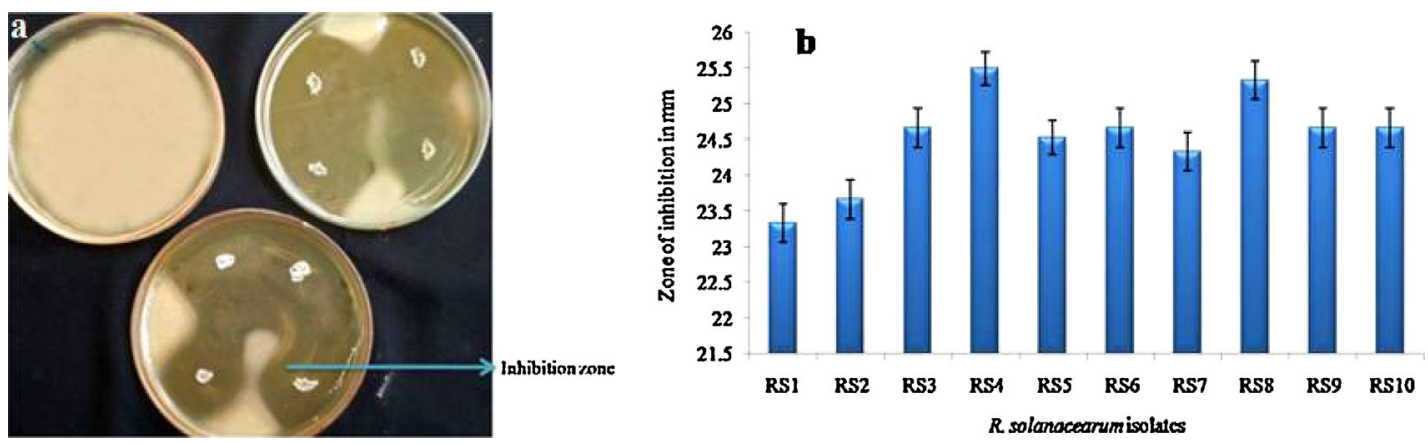

Fig. 1. a) Antagonistic activity by Lactobacillus paracasei, b) inhibition zone of $R$. solanacearum by Lactobacillus paracasei in mm.

10X PCR buffer, a mixture of dNTP's each at a concentration of $200 \mathrm{mM}(1 \mu \mathrm{l})$, sterile double distilled water $(40.75 \mu \mathrm{l}), 2.5 \mathrm{U}$ of Taq polymerase $(0.25 \mu \mathrm{l})$ and template DNA $(1 \mu \mathrm{l})$. PCR amplifying procedure was as follows: $94^{\circ} \mathrm{C}$ for $3 \mathrm{~min}, 35$ cycles at $94^{\circ} \mathrm{C}$ for $40 \mathrm{~s}, 55^{\circ} \mathrm{C}$ for $50 \mathrm{~s}$ and $72{ }^{\circ} \mathrm{C}$ for $2 \mathrm{~min}$. Amplification reaction was performed in thermal cycler (Eppendorf AG Barkhausenweg, Germany). After performing multiple sequence alignment, all sequences were subjected to phylogenetic tree construction using CLUSTAL X2 2.1 (Waterman, 1986). Neighbor Joining (NJ) analysis with 1000 bootstrap replications based on the algorithm. The $16 \mathrm{~S}$ rRNA sequences were submitted to NCBI GenBank and their corresponding accession numbers were obtained as KF924739-KF924748 respectively.

\subsection{Isolation and identification of lactic acid bacteria (LAB)}

Lactic acid bacteria was isolated from rhizosphere soil by standard spread plate technique on MRS (de Man, Rogosa and Sharpe) (Proteose peptone $10 \mathrm{~g}$, Beef extract $10 \mathrm{~g}$, Yeast extract $5 \mathrm{~g}$, Dextrose $20 \mathrm{~g}$, Polysorbate- $801 \mathrm{~g}$, Ammonium citrate $2 \mathrm{~g}$, Sodium acetate $5 \mathrm{~g}$, Magnesium sulfate $0.1 \mathrm{~g}$, Manganese sulfate $0.05 \mathrm{~g}$, Dipotassium phosphate $2 \mathrm{~g}$, Agar $15 \mathrm{~g}$ in $1000 \mathrm{ml}$ of distilled water) agar medium. Serially diluted soil samples were used for Lactic acid bacteria isolation. $100 \mu \mathrm{l}$ soil suspensions were spread on MRS agar plates. Isolates were maintained on MRS plates. Plates were incubated at $35^{\circ} \mathrm{C}$ for $24 \mathrm{~h}$. The lactic acid bacterium was identified based on their morphological and microscopic characteristics. The genomic DNA was extracted from LAB and the 16S rRNA gene amplified by PCR with primers S1 (5'-AGAGTTTGATC (AC) TGGCTCAG-3') et S2 (5'-GG (AC) TACCTTGTTACGA (TC) TTC- $\left.3^{\prime}\right)$. The PCR reaction mixture contained $0.5 \mu$ l of template DNA, $2.5 \mu$ l of reverse primer $(10 \mathrm{mM}), 2.5 \mu \mathrm{l}$ of forward primer $(10 \mathrm{mM}), 2 \mu \mathrm{l}$ of dNTP (25 mM), $4 \mu \mathrm{l}$ of $\mathrm{MgCl}_{2}(25 \mathrm{mM}), 5 \mu \mathrm{l}$ of PCR buffer $(10 \times)$ and $1 \mu \mathrm{l}$ Taq polymerase, in a $50 \mu \mathrm{l}$ final volume. PCR procedure was as follows: $94^{\circ} \mathrm{C}$ for $3 \mathrm{~min}, 29$ cycles at $94^{\circ} \mathrm{C}$ for $40 \mathrm{~s}, 55^{\circ} \mathrm{C}$ for $50 \mathrm{~s}$ and $72{ }^{\circ} \mathrm{C}$ for $2 \mathrm{~min}$. The obtained nucleotide sequences were analyzed using the blast tool of NCBI in order to check the identity with the sequences present in the database (http://blast.ncbi.nlm.nih.gov/ Blast.cgi) (Malini and Savitha, 2012).

\subsection{Antagonistic activity LAB against $\mathrm{R}$. solanacearum}

The isolated LAB was screened for the antagonistic activity against $R$. solanacearum by agar overlay method. $R$. solanacearum was spread on Tryptic Soy agar (TSA) plate and point inoculated with LAB in the center (Jacobsen et al., 1999). The Plates were incubated at $30^{\circ} \mathrm{C}$ for $22 \mathrm{~h}$ following which the zone of inhibition was measured in $\mathrm{mm}$. The zone of inhibition ranged from an average of 23-25 mm (Fig. 1).

\subsection{Preparation of bacterial inoculum}

One highly virulent inoculum of the pathogen was prepared by culturing it in CPG broth (Casamino acid1 $\mathrm{g}$, peptone $10 \mathrm{~g}$, glucose $5 \mathrm{~g}$ in $1000 \mathrm{ml}$ of distilled water) (Kleman 1954) at $28^{\circ} \mathrm{C}$ for $48 \mathrm{~h}$ on rotary shaker at $150 \mathrm{rpm}$. Culture broth was centrifuged at $12,000 \mathrm{rpm}$ for $10 \mathrm{~min}$ at $10^{\circ} \mathrm{C}$. The pellet was resuspended in distilled water and bacterial suspensions were spectrophotometrically adjusted to O.D $600 \mathrm{~nm}=0.1$ (approximately $1 \times 10^{8}$ colony forming unit (cfu) $\mathrm{ml}^{-1}$ ) (Ran et al., 2005). The selected LAB was subcultured twice at $35^{\circ} \mathrm{C}$ in MRS broth (pH-6.0) without Tween 80 . After incubation, cells were removed from the growth medium by centrifugation $\left(10,000 \mathrm{rpm}\right.$ for $\left.15 \mathrm{~min}, 4^{\circ} \mathrm{C}\right)$ and adjusted to $1 \times 10^{8}$ cfu $\mathrm{ml}^{-1}$.

\subsection{Seed bacterization}

Seed samples of tomato were surface sterilized (Guo et al., 2004) and soaked in $10 \mathrm{ml}$ culture suspension of $\mathrm{LAB}$ amended with $0.2 \%$ caboxymethyl cellulose (CMC) to facilitate adherence of the LAB to the seeds and then incubated at $24 \pm 2{ }^{\circ} \mathrm{C}$ in an incubator rotary shaker at $150 \mathrm{rpm}$ for $6 \mathrm{~h}$. After incubation, the seeds were air dried overnight in sterile petriplates aseptically. Seeds soaked in distilled water amended with $0.2 \% \mathrm{CMC}$ served as control.

\subsection{Induction of defense mechanisms and experimental design}

\subsubsection{Preparations of crude enzyme extractions}

Tomato seeds of Arka Megali were pretreated with LAB suspension for $12 \mathrm{~h}$ and germinated on moist blotter discs placed in 9-cm Petri dishes, at 25 seeds per plate following standard procedure of the International Seed Testing Association (ISTA) (2005). The plates were incubated at $28 \pm 2{ }^{\circ} \mathrm{C}$ for ten days until cotyledons were completely opened. The ten-day-old tomato seedlings were dip inoculated by pouring $10 \mathrm{ml}$ of $R$. solanacearum suspension $\left(1 \times 10^{8} \mathrm{cfu} / \mathrm{ml}\right)$ into a Petri dish. To assess the vigour index, root length and shoot length of an individual seedling was measured. The vigour index (VI) was calculated using the formula: $\mathrm{VI}=$ (mean root length + mean shoot length) (\% germination) (Abdul Baki and Anderson, 1973).

The following treatments were included in the experiment (1) Seedlings raised from untreated seeds (C); (2) Seedlings raised from untreated seeds and challenge inoculated with $R$. solanacearum (T1) (3) Seedlings raised from bacterized (LAB) seeds (T2) and (4) Seedlings raised from bacterized seeds and challenge inoculated with $R$. solanacearum (T3). The inoculated and uninoculated seedlings were harvested at $0,6,8,12,16,18,24,30,32,36,40$, $42,48,54,56,60,64,66$ and $72 \mathrm{~h}$ after challenge inoculation and stored at $-80^{\circ} \mathrm{C}$ for subsequent analysis. Distilled water inoculated samples served as control (Ramamoorthy et al., 2002; Vanitha and 
Umesha, 2008). Total protein content of the samples was quantified by Bradford (1976) method.

\subsubsection{Assay of phenylalanine ammonialyase (PAL)}

One gram of tomato seedlings was macerated to a fine paste in a pre chilled mortar with $1 \mathrm{ml}$ of $25 \mathrm{mM}$ Tris-HC1 buffer ( $\mathrm{pH}$ $8.8)(\mathrm{w} / \mathrm{v} ; 1: 1)$. The homogenate was centrifuged at $10,000 \mathrm{rpm}$ for $30 \mathrm{~min}$ at $4{ }^{\circ} \mathrm{C}$ and the supernatant was used directly for PAL enzyme assay. PAL activity was assayed by the modified procedure of Lisker et al. (1983). The reaction mixture contained $1 \mathrm{ml}$ of enzyme extract, $0.5 \mathrm{ml}$ substrate of $50 \mathrm{~mm}$-phenylalanine, and $0.4 \mathrm{ml}$ of $25 \mathrm{mM}$ borate buffer ( $\mathrm{pH} 8.8$ ). After incubation for $2 \mathrm{~h}$ at $40^{\circ} \mathrm{C}$, the reaction was stopped by the addition of $0.06 \mathrm{ml} 5 \mathrm{~N} \mathrm{HCl}$, and the absorbance was read at $290 \mathrm{~nm}$ against the same volume of reaction mixture without L-phenylalanine that served as blank. The enzyme activity was expressed as mol of trans-cinnamic acid $\mathrm{mg}^{-1}$ protein $\mathrm{h}^{-1}$. The enzyme activity was determined by Spectrophotometric measurement of the production of trans-cinnamic acid from L-phenylalanine. The experiments were repeated thrice (Kavitha and Umesha, 2008).

\subsubsection{Assay of peroxidase activity (POX)}

One gram of tomato seedlings were homogenized in $1 \mathrm{ml}$ of $10 \mathrm{mM}$ phosphate buffer ( $\mathrm{pH} .6 .0$ ) in a pre chilled mortar and pestle. The homogenate was centrifuged at $12,000 \mathrm{rpm}$ for $20 \mathrm{~min}$ at $4{ }^{\circ} \mathrm{C}$ and the supernatant served as enzyme source. Peroxidase enzyme assay was carried out as described by Hammerschmidt et al. (1982) with minor modifications. The reaction mixture $(3 \mathrm{ml})$ consisted of $0.25 \%(\mathrm{v} / \mathrm{v})$ guaiacol in $10 \mathrm{mM}$ potassium phosphate buffer $(\mathrm{pH} 6.0)$ containing $10 \mathrm{mM}$ hydrogen peroxide. Addition of $100 \mu \mathrm{l}$ of crude enzyme extract initiated the reaction, which was measured spectrophotometrically at $470 \mathrm{~nm}$ for $1 \mathrm{~min}$. The change in absorbance at $420 \mathrm{~nm}$ was recorded at $30 \mathrm{~s}$ intervals for $3 \mathrm{~min}$. The enzyme activity was expressed as changes in the absorbance $\mathrm{min}^{-1} \mathrm{mg}^{-1}$ of fresh tissue. The experiments were repeated thrice (Kavitha and Umesha, 2008).

\subsubsection{Assay of polyphenol oxidase (PPO)}

One gram of tomato seedlings were homogenized in $10 \mathrm{mM}$ phosphate buffer ( $\mathrm{pH} 6.0$ ) in a pre chilled mortar and pestle on ice $(\mathrm{w} / \mathrm{v} ; 1: 1)$. The homogenate was centrifuged at $12,000 \mathrm{rpm}$ for $20 \mathrm{~min}$ at $4{ }^{\circ} \mathrm{C}$ and the supernatant served as enzyme source. Polyphenol oxidase activity was determined by the protocol developed by Mayer et al. (1965). The reaction mixture consisted of $1.5 \mathrm{ml}$ of $0.1 \mathrm{M}$ sodium phosphate buffer ( $\mathrm{pH} \mathrm{6.5)}$ and $200 \mu \mathrm{l}$ of the enzyme extract. The reaction was started with the addition of $200 \mu \mathrm{l}$ of $10 \mathrm{mM}$ catechol. The rate of increase in absorbance was measured at $420 \mathrm{~nm}$ for $1 \mathrm{~min}$. The activity was expressed as change in absorbance $\mathrm{min}^{-1} \mathrm{mg}^{-1}$ of fresh tissue. The experiments were repeated three times (Kavitha and Umesha, 2008).

\subsubsection{Assay of $\beta$-1,3-glucanase activity}

The $\beta$-1, 3-glucanase activity was assayed by the laminarin dinitrosalicylate method (Pan et al., 1991). One gram of tomato seedlings were homogenized with $5 \mathrm{ml}$ of sodium acetate buffer (0.05 M with pH 5.0) using pre chilled mortar and pestle at $4{ }^{\circ} \mathrm{C}$. The extract was then centrifuged at $10,000 \mathrm{rpm}$ for $15 \mathrm{~min}$ at $4{ }^{\circ} \mathrm{C}$ and the supernatant was used in enzyme assay. The reaction mixture consisted of $62.5 \mu \mathrm{l}$ of $4 \%$ laminarin and $62.5 \mu \mathrm{l}$ of enzyme extract. The reaction was carried out at $40^{\circ} \mathrm{C}$ for $10 \mathrm{~min}$. The reaction was stopped by adding $375 \mu \mathrm{l}$ of DNS reagent and heating for five min on a boiling water bath. The resulting colored solution was diluted with $4.5 \mathrm{ml}$ distilled water, vortexed and its absorbance at $500 \mathrm{~nm}$ was determined. Enzyme activity was expressed as nmol of glucose released $\mathrm{min}^{-1} \mathrm{mg}^{-1}$ of fresh tissue (Manonmani et al., 2009).

\subsubsection{Estimation of total phenolic compounds}

One gram of seedlings was extracted with $10 \mathrm{ml}$ of $80 \%$ methanol at $70^{\circ} \mathrm{C}$ for $15 \mathrm{~min}$. Reaction mixture was containing $1 \mathrm{ml}$ of methanolic extract and $5 \mathrm{ml}$ of distilled sterilized water and $250 \mu \mathrm{l}$ of Folin Ciocalteau reagent $(1 \mathrm{~N})$. This solution was kept at $25^{\circ} \mathrm{C}$. The absorbance of the developed blue color was measured using a spectrophotometer at $725 \mathrm{~nm}$. Gallic acid was used as the standard. The amount of total phenolics was expressed as microgram catechol $^{-1} \mathrm{mg}^{-1}$ of fresh tissue (Zieslin and Ben-Zaken, 1993).

\subsection{Native-PAGE analysis of POX and PPO enzymes}

The POX and PPO isoforms were examined by discontinuous Native polyacrylamide gel electrophoresis (Native-PAGE) following the procedure of Laemmli, (1970) with slight modifications. Both treated and control tomato seedlings were collected at $24 \mathrm{~h}$ and $32 \mathrm{~h}$ for POX and PPO enzymes, respectively. Samples (POX and $\mathrm{PPO})$ were loaded at $\mu \mathrm{g}$ protein onto $8 \%(\mathrm{w} / \mathrm{v})$ polyacrylamide gels in a vertical mini gel electrophoresis (Bangalore Genei, Bangalore, India). Electrophoresis was performed at a constant voltage of $50 \mathrm{~V}$ initially for $1 \mathrm{~h}$ and of $100 \mathrm{~V}$ to complete electrophoresis.

\subsubsection{Activity staining for POX and PPO after electrophoresis}

Peroxidase isoforms were visualized by soaking the gels in staining solution containing $100 \mathrm{mg}$ benzidine dissolved in $1 \mathrm{ml}$ of absolute alcohol and made up to $40 \mathrm{ml}$ using distilled water. A clear solution was obtained when $500 \mu \mathrm{l}$ of glacial acetic acid was added to the above mixture. At the end, $250 \mu$ l of $\mathrm{H}_{2} \mathrm{O}_{2}$ was added to the filtered solution and gels were incubated in the above solution until blue bands appeared (Schrauwen, 1966). Staining of the isoforms of PPO activity was performed by incubating the gels in $50 \mathrm{mM}$ Tris buffer (pH 6.8) containing $500 \mathrm{mg}$ catechol and $300 \mathrm{mg}$ of L-3,4dihydroxyphenylalanine (L-DOPA) on a rotary shaker. After $10 \mathrm{~min}$ of incubation, dark bands indicative of PPO isoforms appeared in the gel (Kavitha and Umesha, 2008).

\subsection{Biocontrol of bacterial wilt of tomato under field conditions}

The field experiment was conducted at the farmer's plot near Chintamani, Karnataka, India during March-June 2014. A formulation of LAB was prepared on farmyard manure carrier material. One $\mathrm{Kg}$ of carrier material was placed in a metal tray under aseptic conditions and the $\mathrm{pH}$ adjusted range of $6.0-7.0$ by adding $\mathrm{CaCO}_{3}$ at the rate of $15 \mathrm{~g} / \mathrm{kg}$. Finally, the mixtures were packed into a polythene bag and autoclaved for $1 \mathrm{~h}$ at $121^{\circ} \mathrm{C}\left(15 \mathrm{lb} /\right.$ inch $\left.^{2}\right)$. After autoclaving, $400 \mathrm{ml}$ of LAB suspension $\left(1 \times 10^{8} \mathrm{cfu} / \mathrm{ml}\right)$ was added to sterilize carrier material followed by thorough mixing under sterile conditions. They were then packed in sterile polythene bags and stored at $4{ }^{\circ} \mathrm{C}$.

The tomato seeds were sown in protrays filled with sterilized Potting soil (soil, sand and coconut pith compost) and watered regularly. Field study was tested on susceptible tomato cultivar is Arka Meghali, growth chamber conditions were maintained at $28 \pm 1{ }^{\circ} \mathrm{C}$, relative humidity of $90 \pm 5 \%$ and twenty days old healthy seedlings were selected and used for further field study (Mahbou Somo Toukam et al., 2009). The twenty days old seedlings were uprooted from protrays and transplanted to experimental plots formerly treated with LAB farmyard manure mixture in with spacing of $60 \times 90 \mathrm{~cm}$. The individual experimental plot area was $25 \mathrm{~m}^{2}$ containing fourteen rows with $100-150$ seedlings per row and distance between rows were $50 \mathrm{~cm}$. The field was maintained according to the tomato growing conditions (red loamy soil, irrigated regularly). Seedlings were watered daily by drip irrigation and fertilized once with NPK $(4: 4: 4) \mathrm{kg} / \mathrm{m}^{2}$, farmyard manure at $28 \mathrm{~kg} / \mathrm{m}^{2}$, vermicompost at $5 \mathrm{~kg} / \mathrm{m}^{2}$. Tomato plants require around $16 \mathrm{~h}$ of light to grow and set fruit. Plants were maintained in a plot where day and night 


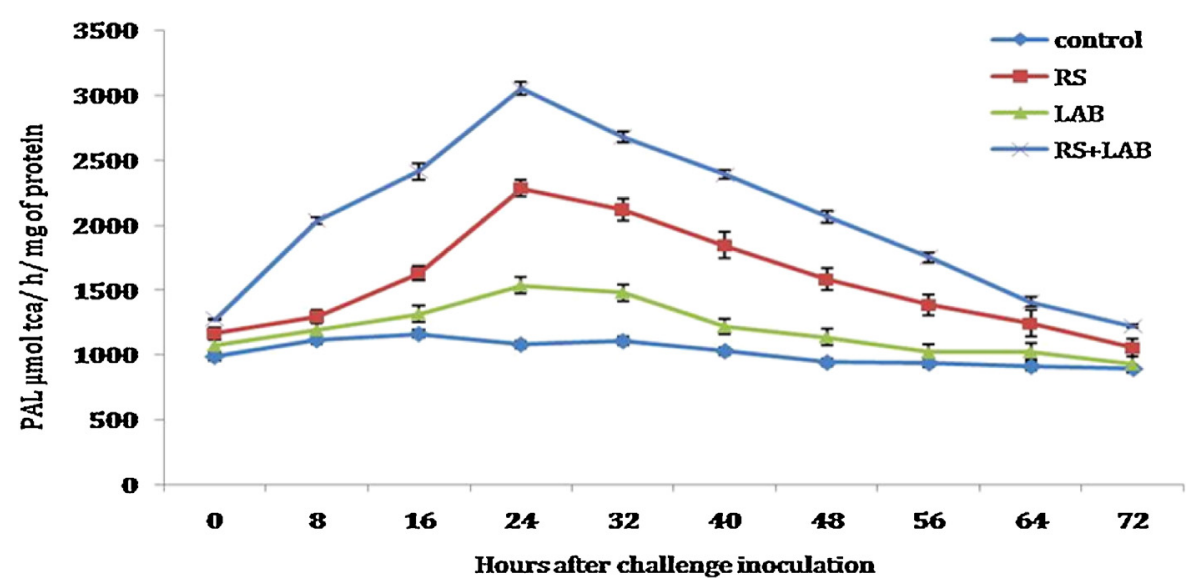

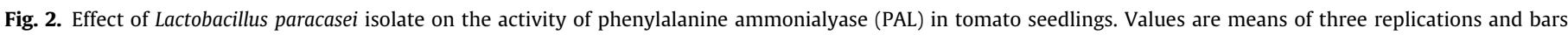
represent $\pm \mathrm{SE}$. C-control, LAB-Lactobacillus paracasei and RS- $R$. solanacearum.

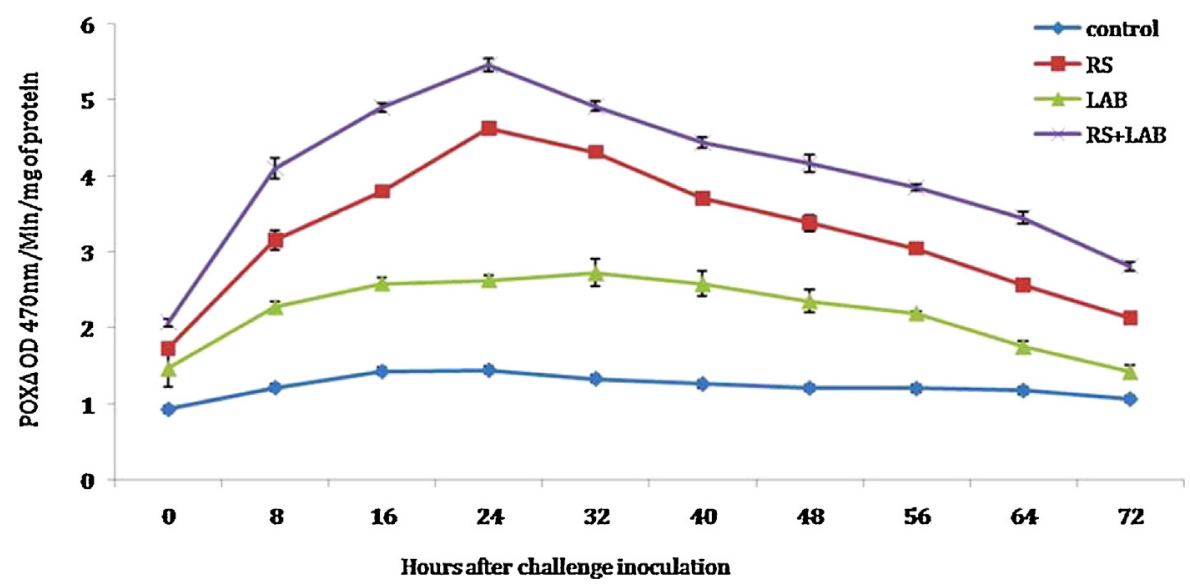

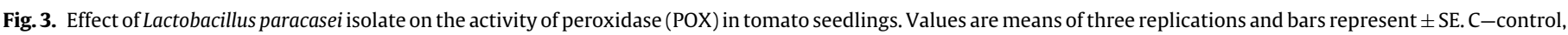
LAB-Lactobacillus paracasei and RS-R. solanacearum.

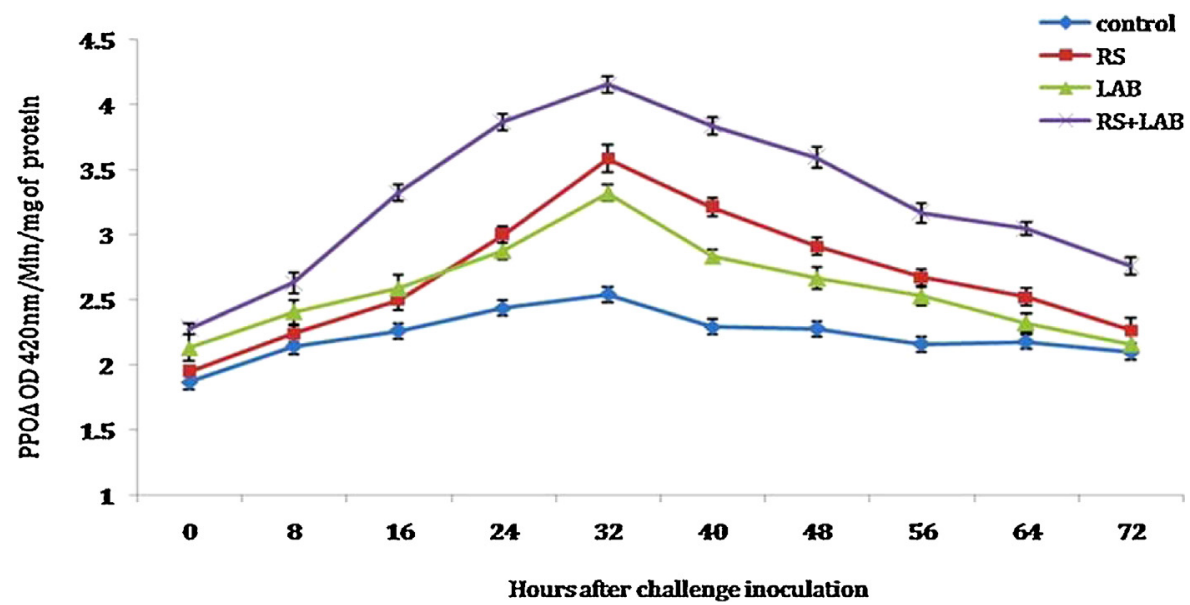

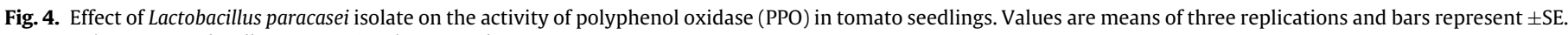
$\mathrm{C}-$ control, LAB-Lactobacillus paracasei and RS-R. solanacearum.

temperatures varied between 25 and $30^{\circ} \mathrm{C}$ (Wydra and Semrau, 2005).

After ten days of transplantation, the plants were challenge inoculated with $48 \mathrm{~h}$ old $R$. solanacearum suspension $\left(1 \times 10^{8} \mathrm{cfu} / \mathrm{ml}\right)$ with five $\mathrm{ml}$ per plant by soil treatment. The percentage (\%) of wilt incidence was calculated by using the formula given below.

$\%$ Wilt incidence $=\frac{\text { No. of plants wilted in each treatment } \times 100}{\text { Total no. of plants receiving the treatment }}$
The number of wilted plants in each treatment was continuously recorded up to 90 days after pathogen treatments, plant height, fresh weight, fruits per plants and tomato yield was determined $\left(\mathrm{kg} / \mathrm{m}^{2}\right)$ at the time of harvest. Tomato fruits were periodically harvested at the end of the experiment. The harvested fruits were weighed and summed average fruit weight then, yield per plot was converted to $\mathrm{kg} / \mathrm{m}^{2}$ (Wydra and Semrau, 2005) and the entire experiment was repeated thrice. 


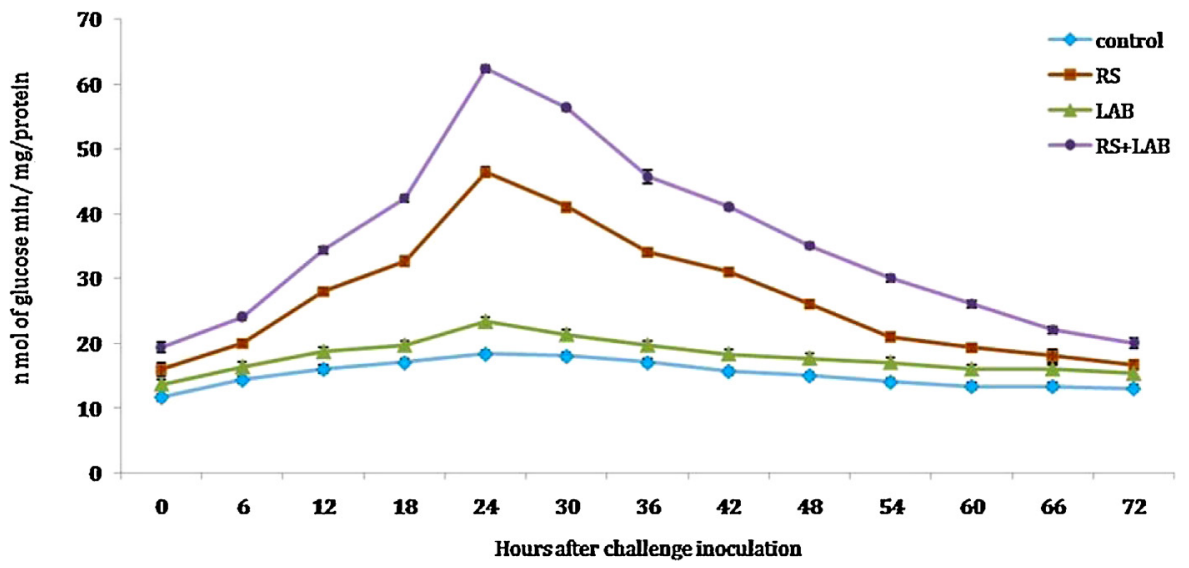

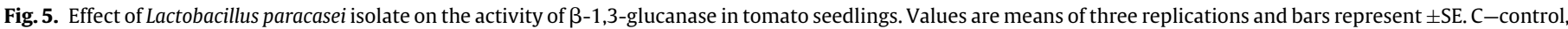
LAB-Lactobacillus paracasei and RS-R. solanacearum.

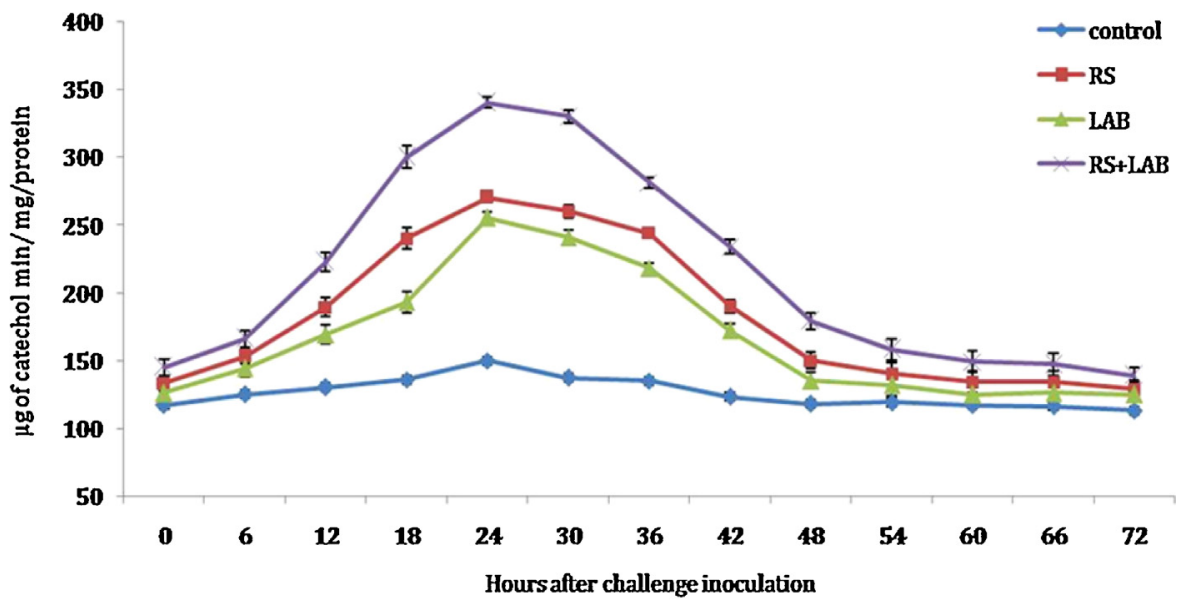

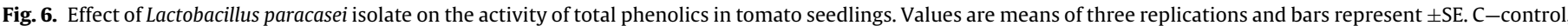
LAB-Lactobacillus paracasei and RS-R. solanacearum.

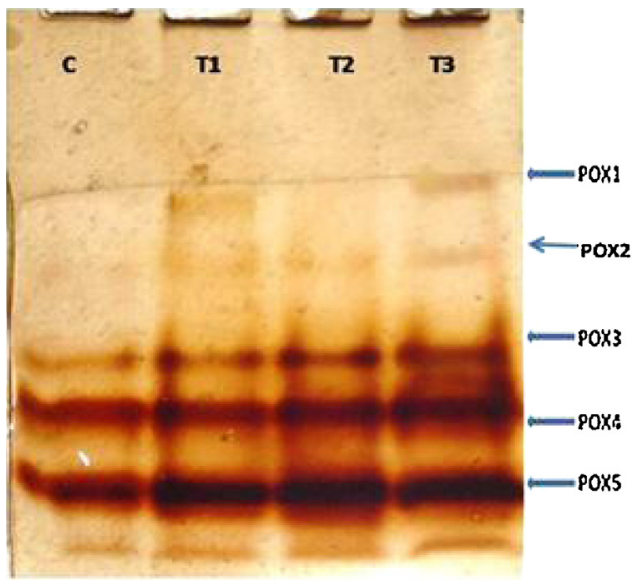

Fig. 7. Native PAGE analyses for peroxidase (POX) isoforms induced by Lactobacillus paracasei in tomato seedlings challenged with or without the pathogen Ralstonia solanacearum. C-untreated seedlings (control), T1-challenge inoculated with $R$. solanacearum, T2-bacterized with Lactobacillus paracasei seedlings and T3-bacterized with Lactobacillus paracasei seedlings and challenge inoculated with R. solanacearum

\subsection{Statistical analysis}

All Data from laboratory and under field conditions experiments were analyzed separately for each experiment and were subjected

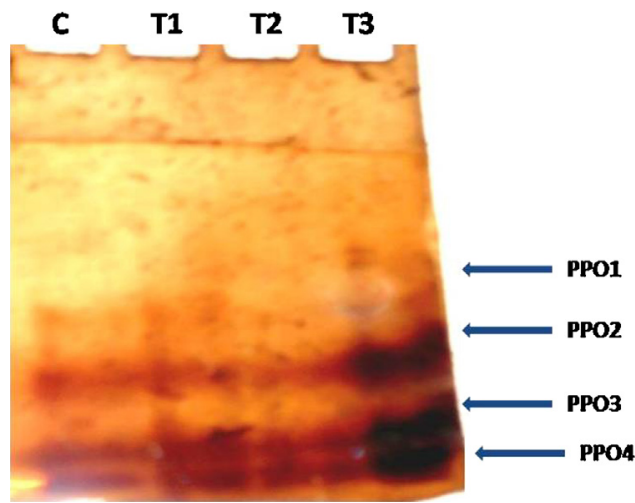

Fig. 8. Native PAGE analyses for Poly phenol oxidase (PPO) isoforms induced by Lactobacillus paracasei in tomato seedlings challenged with or without the pathogen Ralstonia solanacearum. C-untreated seedlings (control), T1-challenge inoculated with $R$. solanacearum, T2-bacterized with Lactobacillus paracasei seedlings and T3-bacterized with Lactobacillus paracasei seedlings and challenge inoculated with R. solanacearum.

to analysis of variance (ANOVA) (SPSS, version 16). Significant effects of treatments were determined by the $F$ values $(P=0.05)$. Treatment means were analyzed using Scheffe post hoc test. 


\section{Results}

\subsection{Isolation and identification of $\mathrm{R}$. solanacearum and lactic acid bacteria}

Ten highly virulent strains were isolated and they were identified as $R$. solanacearum (RS1- RS10). Nine isolates were isolated from rhizosphere soil and one isolate from plant shoot samples. The BLAST analysis of the DNA sequences of the pathogen showed $98 \%$ to $99 \%$ identity to isolates of $R$. solanacearum strains. The morphological and microscopic observations of LAB revealed that the organism was Gram positive rods. The LAB was identified as Lactobacillus paracasei based on blast and phylogenetic analyses of the sequence.

\subsection{Induction of systemic resistance by Lactobacillus paracasei}

\subsubsection{PAL activity}

The activity of PAL enzyme was estimated and detected in LAB treated seedlings, which were challenge inoculated with $R$. solanacearum. Maximum PAL activity was observed at $24 \mathrm{~h}$ after inoculation (hpi). Phenylalanine ammonialyase activity increased in LAB pretreated seedlings challenge inoculated with $R$. solanacearum while seedlings inoculated with $R$. solanacearum alone had lower PAL activity and seedlings treated with only LAB remained almost unchanged but slightly higher activity compared to control (Fig. 2).

\subsubsection{POX activity}

Activity of POX increased after microbial treatments and reached maximum at $24 \mathrm{~h}$. Tomato seedlings inoculated with R.solanacearum recorded lower POX activity than treated seedlings. The seedlings treated with LAB alone demonstrated higher activity than the untreated control. Highest activity of POX was in LAB treated seedlings challenge inoculated with $R$. solanacearum (Fig. 3).

\subsubsection{PPO activity}

Treatment with LAB on tomato seedlings exhibited ISR associated with enhanced PPO activities. The activity of PPO was maximal at $32 \mathrm{~h}$ in seedlings treated with LAB and challenge inoculated with $R$. solanacearum. Seedlings treated with $R$. solanacearum alone also showed increased PPO activity (Fig. 4).

\subsection{4. $\beta$-1, 3-glucanase activity}

A significant increase in $\beta$-1,3-glucanase activity was also observed in tomato seedlings treated with LAB and $R$. solanacearum. The $\beta$-1,3-glucanase activity increased after challenge inoculation, reached the highest level at $24 \mathrm{~h}$ and declined thereafter. Treatment with LAB increased $\beta$-1,3-glucanase activity compared to the control (Fig. 5).

\subsubsection{Total phenolic compounds}

Treatment of tomato seedlings with LAB resulted in high phenol accumulation in plant extracts. Seedlings treatment of LAB resulted in maximum accumulation of phenolics ( $340 \mu \mathrm{g}^{-1} \mathrm{mg}^{-1}$ catechol) when compared to the control ( $120 \mu \mathrm{g}^{-1} \mathrm{mg}^{-1}$ catechol). The phenolics accumulation increased after challenge inoculation with $R$. solanacearum and reached the maximum level on $24 \mathrm{~h}$ (Fig. 6).

\subsection{Native PAGE analysis of peroxidase (POX) and poly phenol oxidase (PPO)}

The protein samples of seedlings of tomato were analyzed for expression of POX. Native PAGE analysis revealed five POX isoforms designated as POX1, POX2, POX3, POX4 and POX5. The expression of
POX3 and POX4 were more prominent in T3 treatment. The intensities of the bands observed in T1 and T2 treatments were lower as compared to T3. Protein extracts from control exhibited only 2 isozymes when compared to other treatments (Fig. 7). The protein samples of treated and untreated tomato seedlings were analyzed for expression of PPO isoforms. Differences in number and intensity of isoforms were observed between T1, T2, T3 and control seedlings. Totally four isoforms of PPO, PPO1, PPO2, PPO3 and PPO4 were expressed in seedlings raised from LAB treated seedlings and challenge inoculated with $R$. solanacearum (T3), compared to control seedlings. The isoforms PPO3 and PPO4 exhibited higher activity in T3 treatment when compared to control. The four PPO isoforms expressed lower intensity bands in the control lane than the other bacterized treatments (T1-T3) (Fig. 8).

\subsection{Biocontrol of bacterial wilt of tomato under field conditions}

In the field study, the control plots yielded an average of $145.7 \mathrm{~kg} / \mathrm{m}^{2}$ and with ten $R$. solanacearum treated plot yielded an average of $32.4-50 \mathrm{~kg} / \mathrm{m}^{2}$. Seedlings treated with LAB an average of $153.5 \mathrm{~kg} / \mathrm{m}^{2}$ tomato yield. As compared to the control, LAB increased the yield by $15.3 \%\left(8.2 \mathrm{~kg} / \mathrm{m}^{2}\right)$. Seedlings treated with both $R$. solanacearum and LAB gave an average of $125.2 \mathrm{~kg} / \mathrm{m}^{2}$ tomato yield as compared to control. As compared to the infected plots, LAB treatment increased the yield by $55 \%\left(28.3 \mathrm{~kg} / \mathrm{m}^{2}\right)$. Field experiment results indicated that LAB exhibited $61.1 \%$ of disease reduction of tomato bacterial wilt (Table 2). The results correlated with that of pot and field trials. The biocontrol agents were found to be effective in the control of bacterial wilt of tomato as chemical replacement. Hence they may be used as potent biocontrol agents in the management of bacterial wilt of tomato.

\section{Discussion}

LABs have been isolated from soil, vegetables surfaces and the rhizosphere, suggesting that they may have the ability to colonise plant roots. The root colonizing capacity of LAB studied here may also be due to their plant growth-promoting effects and capacity of LAB which define their capacity to control bacterial soft rot caused by Pectobacterium (Shrestha et al., 2009). Lactic acid bacterial strains KLF01, KLC02 and KPD03 have shown antagonistic activity against in vitro against $R$. solanacearum and strains KLF01 and KLC02 against Pectobacterium carotovorum under greenhouse and field experiments, respectively. The phosphate solubilizing activities of three LABs was evident, and has increased plant height, weight and chlorophyll content of plants treated with LAB (Anupama et al., 2014). Hamed et al. (2011) reported LAB for the first time in the biocontrol and verified their potential and efficacy as a biocontrol agent for protection of tomato plants which greatly enhanced overall plant growth against control. In the present study, culture broth of LAB was used for seeds pretreatment and has increased the germination (6\%) and seedling vigour index (259) compared with control (Table 1). LAB might have enriched the rhizosphere area with nutrient availability and subsequently encouraged growth of other beneficial microorganisms.

The capability of LAB to trigger induced systematic resistance to enhance production of growth regulators, stimulants, or plant hormones is well known (Shadia et al., 2014). The current study was aimed to determine the effect of Lactobacillus paracasei on tomato seed germination, induced systematic resistance and efficacy of LAB under field against $R$. solanacearum. Under greenhouse conditions LAB against bacterial wilt of tomato as published previously (Narasimha Murthy et al., 2012). Lactobacillus paracasei has shown to possess antagonistic activity against bacterial wilt pathogen $R$. solanacearum in laboratory by excreting lytic enzymes. The effi- 
Table 1

Effect of seed treatment with L. paracasei on tomato seed germination and seedling vigour under laboratory conditions.

\begin{tabular}{|c|c|c|c|c|c|c|}
\hline Treatment & Germination (\%) & $\operatorname{MRL}(\mathrm{cm})$ & $\operatorname{MSL}(\mathrm{cm})$ & Fresh weight & Dry weight & VI \\
\hline Control & $92.66 \pm 5.75^{\mathrm{ad}}$ & $5.40 \pm 0.66^{\mathrm{ac}}$ & $9.36 \pm 1.12^{\mathrm{cd}}$ & $1.08 \pm 0.01^{\mathrm{bc}}$ & $0.28 \pm 0.025^{a}$ & $1368.43 \pm 15.66^{\text {bd }}$ \\
\hline RS1 & $34.0 \pm 1.52^{\mathrm{bc}}$ & $2.95 \pm 0.043^{b c}$ & $3.32 \pm 0.025^{\mathrm{ad}}$ & $0.40 \pm 0.033^{\mathrm{a}}$ & $0.12 \pm 0.003^{a b}$ & $213.41 \pm 5.77^{b c}$ \\
\hline RS2 & $35.0 \pm 1.15^{\mathrm{bd}}$ & $2.59^{\mathrm{ab}} \pm 0.011^{\mathrm{ab}}$ & $3.16 \pm 0.057^{\mathrm{ac}}$ & $0.37 \pm 0.011^{\mathrm{ad}}$ & $0.13 \pm 0.006^{\mathrm{ac}}$ & $201.57 \pm 6.35^{\mathrm{ad}}$ \\
\hline RS3 & $32.66 \pm 1.2^{\mathrm{a}}$ & $2.75 \pm 0.057^{c}$ & $3.26 \pm 0.025^{\mathrm{b}}$ & $0.37 \pm 0.05^{\mathrm{ac}}$ & $0.12 \pm 0.002^{\mathrm{a}}$ & $196.64 \pm 3.46^{\mathrm{ac}}$ \\
\hline RS4 & $35.33 \pm 1.15^{\mathrm{ab}}$ & $2.65 \pm 0.011^{\mathrm{ab}}$ & $3.11 \pm 0.033^{\mathrm{b}}$ & $0.40 \pm 0.057^{c}$ & $0.12 \pm 0.001^{\mathrm{ac}}$ & $203.67 \pm 5.77^{\mathrm{ad}}$ \\
\hline RS5 & $34.33 \pm 0.88^{\mathrm{ad}}$ & $2.40 \pm 0.011^{\mathrm{abc}}$ & $3.17 \pm 0.057^{\mathrm{ac}}$ & $0.34 \pm 0.033^{\mathrm{ad}}$ & $0.12 \pm 0.003^{d}$ & $191.59 \pm 6.57^{a}$ \\
\hline RS6 & $35.66 \pm 1.12^{\mathrm{ac}}$ & $2.57 \pm 0.033^{\mathrm{ab}}$ & $3.17 \pm 0.012^{\mathrm{a}}$ & $0.35 \pm 0.066^{\mathrm{ac}}$ & $0.12 \pm 0.003^{\mathrm{ad}}$ & $204.86 \pm 5.19^{\mathrm{ac}}$ \\
\hline RS7 & $34.0 \pm 1.86^{\mathrm{ac}}$ & $2.50 \pm 0.028^{\mathrm{ad}}$ & $3.19 \pm 0.045^{\mathrm{ac}}$ & $0.45 \pm 0.025^{\mathrm{ac}}$ & $0.12 \pm 0.005^{\mathrm{b}}$ & $193.60 \pm 4.61^{c}$ \\
\hline RS8 & $35.0 \pm 1.7^{\mathrm{ab}}$ & $2.85 \pm 0.057^{\mathrm{ab}}$ & $3.18 \pm 0.066^{a c}$ & $0.40 \pm 0.011^{\mathrm{bd}}$ & $0.12 \pm 0.006^{\mathrm{bd}}$ & $211.35 \pm 3.46^{\mathrm{ab}}$ \\
\hline RS9 & $34.66 \pm 1.12^{\mathrm{ac}}$ & $2.68 \pm 0.011^{\mathrm{a}}$ & $3.15 \pm 0.033^{c}$ & $0.36 \pm 0.021^{\mathrm{bc}}$ & $0.12 \pm 0.005^{\mathrm{d}}$ & $202.41 \pm 4.61^{\mathrm{ab}}$ \\
\hline RS10 & $35.33 \pm 1.57^{d}$ & $2.67 \pm 0.033^{\mathrm{ab}}$ & $3.24 \pm 0.057^{d}$ & $0.36 \pm 0.011^{\mathrm{c}}$ & $0.12 \pm 0.003^{b c}$ & $209.11 \pm 6.92^{\mathrm{abc}}$ \\
\hline L. paracasei & $98.60 \pm 3.46^{\mathrm{ac}}$ & $5.66 \pm 0.57^{b c}$ & $9.53 \pm 1.6^{\mathrm{bd}}$ & $1.36 \pm 0.11 \mathrm{a}^{\mathrm{cd}}$ & $0.38 \pm 0.03^{\mathrm{cd}}$ & $1527.86 \pm 20.33^{b c}$ \\
\hline
\end{tabular}

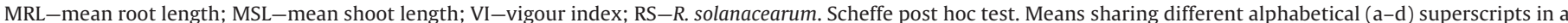
column significantly different $(\mathrm{P} \leq 0.05)$.

Table 2

Effect of LAB on tomato plant growth and fruits yield under field conditions.

\begin{tabular}{|c|c|c|c|c|c|c|}
\hline Treatments & Plant height $(\mathrm{cm})$ & Fresh weight(g) & Dry weight(g) & Fruits/plant & Fruit yield $\mathrm{kg} / \mathrm{m}^{2}$ & Disease Incidence (\%) \\
\hline Control & $62.7 \pm 1.44^{\mathrm{cd}}$ & $435.5 \pm 0.57^{b}$ & $29.7 \pm 2.3^{b c}$ & $39.6 \pm 1.15^{\mathrm{abc}}$ & $145.7 \pm 5.77^{\text {bde }}$ & $0.0 \pm 00^{\mathrm{a}}$ \\
\hline RS1 & $31.4 \pm 0.73^{\mathrm{ab}}$ & $157.7 \pm 0.88^{\mathrm{bc}}$ & $12.4 \pm 2.11^{\mathrm{ab}}$ & $9.5 \pm 1.11^{\mathrm{ad}}$ & $33.6 \pm 1.73^{\mathrm{ac}}$ & $99.48 \pm 5.77^{\text {cde }}$ \\
\hline RS2 & $29.5 \pm 1.23^{\mathrm{cd}}$ & $136.5 \pm 3.33^{\mathrm{acd}}$ & $12.5 \pm 2.2^{\mathrm{abc}}$ & $10.7 \pm 2.33^{\mathrm{ac}}$ & $37.5 \pm 1.6^{\mathrm{bd}}$ & $95.4 \pm 4.57^{\mathrm{ac}}$ \\
\hline RS3 & $26.6 \pm 1.57^{c d}$ & $122.6 \pm 4.57^{\mathrm{ad}}$ & $17.3 \pm 1.57^{\mathrm{cd}}$ & $9.4 \pm 1.66^{\mathrm{ad}}$ & $32.4 \pm 2.21^{\mathrm{ac}}$ & $96.5 \pm 3.66^{\mathrm{acd}}$ \\
\hline RS4 & $29.4 \pm 1.34^{\mathrm{abc}}$ & $124.7 \pm 3.63^{\mathrm{cd}}$ & $15.6 \pm 1.66^{\mathrm{ab}}$ & $11.4 \pm 2.12^{\mathrm{cd}}$ & $42.6 \pm 3.4^{\mathrm{abc}}$ & $93.7 \pm 5.33^{\mathrm{bcd}}$ \\
\hline RS5 & $30.7 \pm 2.21^{\mathrm{bd}}$ & $145.3 \pm 5.54^{\mathrm{abc}}$ & $14.7 \pm 2.21^{\mathrm{bcd}}$ & $12.3 \pm 1.57^{\mathrm{de}}$ & $45.8 \pm 3.7^{\mathrm{ad}}$ & $94.6 \pm 6.66^{\text {abe }}$ \\
\hline RS6 & $31.4 \pm 2.45^{\text {cde }}$ & $155.4 \pm 3.21^{\mathrm{ae}}$ & $13.8 \pm 3.12^{\mathrm{ac}}$ & $10.5 \pm 1.33^{a b c}$ & $40.6 \pm 2.8^{\mathrm{abc}}$ & $97.4 \pm 4.57^{\mathrm{bc}}$ \\
\hline RS7 & $28.6 \pm 1.66^{\mathrm{de}}$ & $133.8 \pm 4.66^{\mathrm{bcd}}$ & $16.3 \pm 2.32^{\mathrm{bc}}$ & $13.6 \pm 1.57^{\text {cde }}$ & $50.0 \pm 4.3^{\text {cde }}$ & $97.2 \pm 3.8^{\text {bde }}$ \\
\hline RS8 & $29.6 \pm 2.3^{\text {ace }}$ & $149.9 \pm 2.43^{\mathrm{cd}}$ & $17.9 \pm 1.98^{\mathrm{cd}}$ & $11.8 \pm 1.13^{\mathrm{acd}}$ & $44.0 \pm 3.8^{\mathrm{ab}}$ & $95.7 \pm 4.57^{\mathrm{abc}}$ \\
\hline RS9 & $28.8 \pm 1.34^{\mathrm{ab}}$ & $145.6 \pm 3.34^{\mathrm{ad}}$ & $14.8 \pm 2.3^{\text {ade }}$ & $10.5 \pm 1.26^{\mathrm{ab}}$ & $40.6 \pm 2.6^{\mathrm{cd}}$ & $96.8 \pm 5.66^{\mathrm{ae}}$ \\
\hline RS10 & $29.6 \pm 3.57^{\mathrm{acd}}$ & $156.4 \pm 2.66^{\mathrm{e}}$ & $16.3 \pm 2.12^{\mathrm{ae}}$ & $9.8 \pm 0.94^{\mathrm{b}}$ & $36.6 \pm 2.5^{\mathrm{bc}}$ & $94.4 \pm 4.43^{\mathrm{de}}$ \\
\hline L. paracasei & $90.4 \pm 4.73^{\text {de }}$ & $680.6 \pm 1.15^{\mathrm{bcd}}$ & $41.12 \pm 3.33^{\text {cde }}$ & $41.6 \pm 3.2^{\mathrm{abc}}$ & $153.5 \pm 4.65^{\text {cde }}$ & $0.0 \pm 00^{\mathrm{a}}$ \\
\hline R.solanacearum and L. paracasei & $68.8 \pm 3.15^{\mathrm{ab}}$ & $320.9 \pm 0.66^{\mathrm{acd}}$ & $35.9 \pm 3.15^{\mathrm{abc}}$ & $29.9 \pm 2.66^{\mathrm{acd}}$ & $125.2 \pm 4.61^{\mathrm{ac}}$ & $38.7 \pm 1.12^{\mathrm{ab}}$ \\
\hline
\end{tabular}

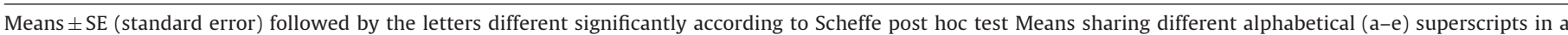
column significantly different $(\mathrm{P} \leq 0.05)$.

ciency of plant growth promotion by Lactobacillus may mainly depend on their timely establishment and persistence throughout the growing season at sites where the pathogens are active. Many of the LABS, mainly Lactobacillus paracasei, have been isolated from suppressive soil for the management of bacterial wilt. Plants are able to protect themselves upon various phytopathogen attacks by producing a wide spectrum of defence enzymes that improve both cellular protection and disease resistance. Inducing the plant's own defense mechanisms by prior application of a biological inducer is thought to be a novel plant defense strategy (Hamed et al., 2011).

In the present study, an attempt has been made to study the induced systemic resistance in tomato against $R$. solanacearum by considering the lactic acid bacteria under laboratory conditions. Application of biocontrol agent, LAB with accumulation of high levels of phenolics and activities of PAL, POX, PPO and $\beta-1$, 3-glucanase in tomato compared to other treatments and control. Enhanced PAL and POX activity was studied in tomato plants infected by bacterial wilt. Our findings support that quick and high induction of PAL and POX were observed in Lactobacillus paracasei pretreated tomato seedlings, which were challenge inoculated with $R$. solanacearum. In the present study, increased activity of PAL and POX was recorded in tomato seedlings treated with $L$. paracasei after challenge inoculation with the pathogen. In our study, a significant increase in PAL activity till 24 hpi was observed indicating the induction of resistance in host plants. The control seedlings with or without pathogen infection reported the lowest PAL activity without much variation. However, the seedlings inoculated with the LAB isolate alone also exhibited high PAL activity in comparison with the control. Peroxidase catalyzes the last step in the biosynthesis of lignin and other oxidative phenols. Seed treatment with LAB induced the defense related activities of POX. Our study indicated a significant increase in POX activity at 24 hpi, observed in the LAB treated seedlings challenge inoculated with $R$. solanacearum suggesting the induction of resistance in tomato plants. The control seedlings reported lowest POX activity with or without pathogen infection. However, the seedlings inoculated with LAB isolate alone also exhibited high POX activity in comparison with the control.

Seed treatment with LAB induced the defense related activities of PPO. Polyphenol oxidase is a copper containing enzyme, oxidizing phenolics to highly toxic quinines and is involved in the terminal oxidation of diseased plant tissue and it is attributed for its role in disease resistance. Also in our study, tomato seedlings treated with LAB, the induced systemic resistance was linked with enhanced PPO activities. Significant increase in PPO activity at $32 \mathrm{hpi}$, observed LAB treated seedlings challenge inoculated with $R$. solanacearum. Various rhizobacteria induced PPO activity in cucumber root tissues (Chen et al., 2000).

Seed treatment with LAB also finds the high accumulation of phenols in plant extracts when compared to the control; the maximum level being attained at $24 \mathrm{hpi}$. The presence of phenols in plants and their synthesis in response to disease is connected with resistance and studies have indicated that highest accumulation of phenolics due to increased PAL activity offered defense against diseases. Induced accumulation of phenolics and lignins into cell walls acts by strengthening the cell wall and also by releasing antimicrobial compounds, which leads to a resistance response.

Seed treatment with LAB induced the defense related enzyme activities of $\beta-1,3$ glucanase. Our study revealed a significant increase in $\beta-1,3$ glucanase enzyme activities at $24 \mathrm{hpi}$, observed in the LAB treated seedlings challenge inoculated with $R$. solanacearum indicating the induction of resistance in tomato plants. Synthesis and accumulation of PR proteins have been 
reported to play an important role in plant defense mechanisms. $\beta$-1,3-glucanase has been reported to associate with resistance in plants against pests and diseases (Singh et al., 1999).

Seed application with Trichoderma asperellum isolates induced a significant increased defense enzyme activity in the treated tomato plants. Increased activities of phenylalanine ammonialyase, peroxidase, Polyphenol oxidase, $\beta$-1,3-glucanase, and phenols were observed in T. asperellum pre-treated tomato seedlings challenged with $R$. solanacearum (Narasimha Murthy et al., 2014). Lactic acid bacteria induced resistance against $R$. solanacearum in tomato seedlings is associated with the enhanced expression of genes for defense related enzymes. Pretreatment of tomato plants with LAB triggered the increased PAL, POX, PPO and $\beta$-1,3-glucanase activities in response to attack by $R$. solanacearum.

In conclusion, the defense related enzymes played an important role in ISR. Enzyme accumulation could have been involved not only in plant defense response, but might have also been associated with induced resistance by Lactobacillus paracasei against bacterial wilt disease caused by $R$. solanacearum. The application of biocontrol agent as seed treatment could prove to be a beneficial component of integrated disease management. Accumulation of PAL, Phenolics, $\beta$-1,3-glucanase and induction of POX1-POX5 and PPO1-PPO4 isoforms by Lactobacillus paracasei in tomato seedling tissues might have collectively contributed to induced systemic resistance in tomato plants against $R$. solanacearum. The LAB isolates, apart from their action against bacterial wilt pathogen, are good plant growth promoters in vitro and in vivo and able to induce systemic resistance in tomato plants, which is an added advantage for practical agricultural system. It could be speculated that the enhanced expression patterns of these enzymes by LAB might account for their ability to provide effective protection from bacterial wilt of tomato seedlings caused by $R$. solanacearum.

\section{Acknowledgements}

The authors are grateful to University Grants Commission, Government of India, New Delhi, India for providing UGC-BSR Meritorious Fellowship for first author. The authors also like to thank the Chairman, Department of Microbiology and Biotechnology, Bangalore University, Bangalore, India, for providing the facilities for this research.

\section{References}

Abdul Baki, A.A., Anderson, J.D., 1973. Vigour determination in soybean seed by multiple criteria. Crop Sci. 13, 630-633.

Aliye, N., Fininsa, C., Hiskias, Y., 2008. Evaluation of rhizosphere bacterial antagonists for their potential to bioprotect potato (Solanum tuberosum) against bacterial wilt (Ralstonia solanacearum). Biol. Cont. 47, 282-288.

Anupama, S., Beom, S., Duck, H.P., 2014. Biological control of bacterial spot disease and plant growth promoting effects of lactic acid bacteria on pepper. Biocontrol Sci. Technol. 24, 763-779.

Ariyapitipun, T., Mustapha, A., Clarke, A.D., 1999. Microbial shelf life determination of vacuum packaged fresh beef treated with polylactic acid, and nisin solutions. J. Food Protect. 62, 913-920.

Axel, C., Zannini, E., Coffey, A., Guo, J., Waters, D.M., Arendt, E.K., 2012. Ecofriendly control of potato late blight causative agent and the potential role of lactic acid bacteria. A review. Appl. Microbiol. Biotechnol. 96, 37-48.

Bradford, M.M., 1976. A rapid and sensitive method for quantification of microgram quantities of protein utilizing the principle of protein due binding. Anal. Biochem. 72, 248-254.

Chen, W.P., Kuo, T.T., 1993. A simple and rapid method for the preparation of Gram-negative bacterial genomic DNA. Nucleic Acids Res. 21, 2260.

Chen, C., Belanger, R.R., Benhamou, N., Paulitz, T.C., 2000. Defense enzymes induced in cucumber roots by treatment with plant growth promoting rhizobacteria (PGPR). Physiol. Mol. Plant 56, 13-23.

Das, K.K., Panda, D., Nagaraju, M., Sharma, S.G., Sarkar, R.K., 2004. Antioxidant enzymes and aldehyde releasing capacity of rice cultivars (Oryzae sativa L.) and determinants of anaerobic seedling establishment capacity. Bulg. J. Plant Physiol. 30, 34-44.
El-Mabrok, A.S.W., Hassan, Z., Mokhtar, A.M., Hussain, K.M.A., Kahar, F.K.S.B.A., 2012. Screening of lactic acid bacteria as biocontrol against (Colletotrichum capsici) on chilli Bangi. Res. J. Appl. Sci. 7, 466-473.

Girish, N., Umesha, S., 2005. Effect of plant growth promoting rhizobacteria on bacterial canker of tomato. Arch. Phytopathol. Plant Protect. 38, 235-243.

Glick, B.R., 1995. The enhancement of plant growth by free living bacteria. Can. J. Microbiol. 41, 109-114.

Glick, B.R., 2014. Bacteria with ACC deaminase can promote plant growth and help to feed the world. Microbiol. Res. 169, 30-39.

Goswami, D., Thakker Dhandhukia, J.N.P.C., 2016. Portraying mechanics of plant growth promoting rhizobacteria (PGPR): a review cogent food and agriculture. Soil Crop Sci. 2, 1127500.

Guo, J.H., Qi, H.Y., Guo, Y.H., Ge, H.L., Gong, L.Y., Zhang, L.X., Sun, P.H., 2004. Biocontrol of tomato wilt by plant growth-promoting rhizobacteria. Biol. Control 29, 66-72

Hamed, H.A., Moustafa, Y.A., Abdel-Aziz, S.M., 2011. In vivo efficacy of lactic acid bacteria in biological control against Fusarium oxysporum for protection of tomato plant. Life Sci. J. 8, 462-468.

Hammerschmidt, R., Nuckles, E.M., Kuc, J., 1982. Association of enhanced peroxidase activity with induced systemic resistance of cucumber to Colletotrichum lagenarium. Physiol. Mol. Plant Pathol. 20, 73-82.

International Seed Testing Association (ISTA), 2005. Proceedings of the international seed testing association. International rules of seed testing. Seed Sci. Technol. 15, A1-A9.

Jacobsen, C.V., Rosenfeldt, V., Hayford, A.E., Moller, P.L., Michaelsen Paerregaard, K.F., 1999. Screening of probiotic activities of forty-seven strains of Lactobacillus spp. by in vitro techniques and evaluation of the colonization ability of five selected strains in humans. J. Appl. Microbiol. 11, 4949-4956.

Kavitha, R., Umesha, S., 2008. Regulation of defense-related enzymes associated with bacterial spot resistance in tomato. Phytoparasitica 36, 144-159.

Kelman, A., 1954. The relationship of pathogenicity of Pseudomonas solanacearum to colony appearance in tetrazolium medium. Phytopathology 44, 693-695.

Laemmli, U.K., 1970. Cleavage of structural proteins during the assembly of the head of bacteriophage T4. Nature 227, 680-685.

Lane, D.J., 1991. 16S/23S rRNA Sequencing. In: Stackebrandt, I.E., Good Fellow, M. (Eds.), Nucleic Acid Techniques in Bacterial Systematics. John Wiley, Brisbane, Australia, pp. 115-147.

Lisker, N., Cohen, I., Chalutz, E., Fucus, Y., 1983. Fungal infections suppress ethylene-induced phenylalanine ammonialyase activity in grape fruits. Physiol. Mol. Plant Pathol. 22, 331-338.

Lutz, M.P., Michel, V., Martinez, C., Camps, C., 2012. Lactic acid bacteria as biocontrol agents of soil-borne pathogens. Biological control of fungal and bacterial plant pathogens. IOBC-WPRS Bull. 78, 285-288.

Mahbou Somo Toukam, G., Cellier, G., Wicker, E., Guilbaud, C., Kahane, R., Allen, C., et al., 2009. Broad diversity of Ralstonia solanacearum strains in Cameroon. Plant Dis. 93, 1123-1130.

Malini, M., Savitha, J., 2012. Detection of heat stable bacteriocin from Lactobacillus acidophilus NCIM5426 by liquid chromatography/mass spectrometry. Indian J. Sci. Technol. 5, 3.

Manonmani, K., Bhaskaran, R., Jagannathan, R., Jayasekhar, M., 2009. Biochemical changes in acid lime during pathogenicity of canker pathogen. Indian Agric. Res. 43, 157-165.

Matthias, P.L, Vincent, M., Chloe, M., Cedric, C., 2012. Lactic acid bacteria as biocontrol agents of soil-borne pathogens: biological control of fungal and bacterial plant pathogens. IOBC-WPRS Bull. 78, 285-288.

Mayer, A.M., Harel, E., Shanl, R.B., 1965. Assay of catechol oxidase: a critical comparison of methods. Phytochemistry 5, 783-789.

Metraux, J.P., Raskin, I., 1993. Biotechnology in Plant Disease Control. In: Ihan, C. (Ed.). Wiley-Liss Inc., London, pp. 191-209.

Nagorska, K., Bikowski, M., Obuchowskji, M., 2007. Multicellular behaviour and production of a wide variety of toxic substances support usage of Bacillus subtilis as a powerful biocontrol agent. Acta Biochim. Polonica 54, 495-508.

Narasimha Murthy, K., Malini, M., Savitha, J., Srinivas, C., 2012. Lactic acid bacteria (LAB) as plant growth promoting bacteria (PGPB) for the control of wilt of tomato caused by Ralstonia solanacearum. Pest Manag. Hortic. Ecosyst. 18, 60-65.

Pan, S.Q., Ye, X.S., Kuc, J., 1991. A technique for detection of chitinase $\beta$-1,3-glucanase and protein patterns after single separation using polyacrylamide electrophoresis or isoelectro focusing. Phytopathology 81 , 970-974.

Ramamoorthy, V., Raguchander, T., Samiyappan, R., 2002. Enhancing resistance of tomato and hot pepper to Pythium diseases by seed treatment with fluorescent pseudomonads. Eur. J. Plant Pathol. 108, 429-441.

Ran, L.X., Liu, C.Y., Wu, G.J., Van Loon, L.C., Bakker, P.A.H.M., 2005. Suppression of bacterial wilt in Eucalyptus urophylla by fluorescent Pseudomonas spp. in China. Biol. Control 32, 111-120.

Ronga, D., Lovelli, S., Zaccardelli, M., Perrone, D., Ulrici, A., Francia, E., Milc, J., Pecchioni, N., 2015. Physiological responses of processing tomato in organic andconventional Mediterranean cropping systems. Sci. Hortic. 190, 161-172.

Roohie, K.R., Umesha, S., 2015. Identification of genes associated with black rot resistance in cabbage through suppression subtractive hybridization. 3 Biotechnology 5, 1089-1100.

Schrauwen, J., 1966. Nachweis Von enzymen nach electrophoretischer trennung an polyacrylamide sauren. J. Chromatogr. 23, 177-180. 
Shadia, M.A.A., Yomna, A.M., Hoda, A.H., 2014. Lactic acid bacteria in the green biocontrol against some phytopathogenic fungi: treatment of tomato seeds. J. Basic Appl. Sci. Res. 4, 1-9.

Shrestha, A., Choi, K., Lim, K.C., Hur, H.J., Cho, S., 2009. Antagonistic effect of Lactobacillus sp: strain KLF01 against soil borne plant pathogen Ralstonia solanacearum. Korean J. Pestic. Sci. 13, 45-53.

Siddikee, M.A., Chauhan, P.S., Anandham, R., Han, G.H., Sa, T., 2010. Isolation, characterization, and use for plant growth promotion under salt stress: of ACC deaminase producing halotolerant bacteria derived from coastal soil. J. Microbiol. Biotechnol. 20, 1577-1584.

Singh, P.P., Shin, Y.C., Park, C.S., Chung, Y.R., 1999. Biological controls of Fusarium wilt of cucumber by chitinolytic bacteria. Phytopathology 89, 92-99.

Stiles, M.E., Holzapfel, W.H., 1997. Lactic acid bacteria of foods and their current taxonomy. Int. J. Food Microbiol. 36, 1-29.

Umesha, S., 2006. Phenylalanine ammonialyase activity in tomato seedlings and its relationship to bacterial canker disease resistance. Phytoparasitica 34, 68-71.

Van Loon, L.C., Bakker, P.A.H.M., Pieterse, C.M.J., 1998. Systemic resistance induced by rhizosphere bacteria. Anl. Rev. Phytopathol. 36, 453-483.

Van Loon, L.C., 1997. Induced resistance in plants and the role of pathogenesis-related proteins. Eur. J. Plant Pathol. 103, 753-765.
Vanitha, S.C., Umesha, S., 2008. Variations in defense related enzyme activities in tomato during the infection with bacterial wilt pathogen. Int. J. Plant Sci. 3 , 245-253.

Villareal, R.L., 1979. Tomato Is the Tropics. Westriew Press, Border, Colorado, pp. 174.

Waterman, M.S., 1986. Multiple sequence alignment by consensus. Nucleic Acids Res. 14, 9095-9102.

Wydra, K., Semrau, J., 2005. Phenotypic and molecular characterization of the interaction of antagonistic bacteria with Ralstonia solanacearum causing tomato bacterial wilt. In: Zeller, W., Ulrich, C. (Eds.), 1st International Symposium on Biological Control of Bacteria Plant Disease. Darmstadt, Germany, pp. 112-118.

Yabuuchi, E., Kosako, Y., Yano, I., Hotta, H., Nishiuchi, Y., 1995. Transfer of two Burkholderia and an Alcaligenes species to Ralstonia gen. Nov.: proposal for Ralstonia pickettii, Ralstonia solanacearum and Ralstonia eutropha. Microbiol. Immunol. 39, 897-904.

Zieslin, N., Ben-Zaken, R., 1993. Peroxidase activity and presence of phenolic substances in peduncles of rose flower. Plant Physiol. Biochem. 31, 333-339. 